\title{
A Phenomenological Study on the Human Rights Violation Experience of Semi-professional Athletes at Workplace
}

\author{
Siwan Han', Hyun Mi Yoo ${ }^{2}$ and Jung Hoon Huh ${ }^{3 *}$ \\ ${ }^{1}$ Department of Physical Education, Dongguk University, Seoul, Korea \\ ${ }^{2}$ Department of Sociology, Seoul National University, Seoul, Korea \\ ${ }^{3}$ Department of Sport Science, Chung-Ang University, Seoul, Korea
}

\author{
Article Info \\ Received 2021.03.11. \\ Revised 2021.07.13. \\ Accepted 2021.07.30. \\ Correspondence* \\ Jung Hoon Huh \\ huhjh@cau.ac.kr

\section{Key Words} \\ semi-professional athletes, \\ human right violation, \\ experience, \\ phenomenological method \\ 본 연구는 저자들이 참여한 2019년 국가인권 \\ 위원회 실업팀 직장 운동선수 인권침해 실태 \\ 조사에서 얻은 자료의 일부를 활용하여 논문 \\ 으로 새롭게 구성한 것임.
}

PURPOSE This study aimed to identify the nature of human rights violations experienced by semi-professional athletes in semi-professional sports teams and explored the relevant cases. METHODS For this purpose, 35 semi-professional athletes (20 men and 15 women) from the semi-professional sports teams participated in the study, and data collection was conducted through in-depth interviews and focus group interviews (FGI). The collected data were analyzed using the phenomenological research method proposed by Colaizzi (1978). RESULTS The study summarized the results into five categories, 14 theme clusters and 41 themes. Its inherent structures include 'first step to becoming a semiprofessional athlete: disadvantageous contracts for players,' 'unavoidable absolute power: obedience to the coach,' 'forced training camp: autonomy and privacy infringement,' 'structural problems of the semi-professional sports federation: tyrannized power' and 'female players who are in male-oriented society: genderfocused than performance.' CONCLUSIONS The results of this study provided an understanding of athletes' human rights violations experienced in semi-professional sports teams. Understanding athletes in semi-professional sports teams through phenomenological research was conducted based on previous studies discussing practical and policy intervention measures.

\section{서론}

지금까지 운동선수에 대한 인권침해 문제의 대부분은 체육계가 구조적 으로 안고 있는 문제로부터 발생하여 그 피해는 선수 개인이 감당해야 하는 상황이었다(Moon \& Kim, 2020). 이러한 상황은 언어적· 신체적· 성폭력이 만연한 스포츠계에 형성된 왜곡된 통념으로 나타나고 있다. 최 근, 프로스포츠 배구선수 학교폭력 사건과 관련하여 스포츠인권이 사회 에 큰 파장을 일으키고 있다. 이 사건은 트라이애슬론 국가대표선수가 사망한 사건(2020년 6월), 쇼트트랙 여자국가대표선수가 코치로부터 장 기간 성폭행 및 폭행을 당한 사실을 폭로한 사건(2019년 1월) 이후에 발 생한 사건이라서 그 충격이 더욱 컸다. 여기서 주목할 점은 '국가인권위 원회 스포츠인권특별조사단에서 선수들의 인권에 대한 전수조사를 실시 하고(2019년 1월), 스포츠윤리센터가 독립기관으로 출범(2020년 8월) 하는 등 범국가적인 스포츠인권정책을 실시하여도 스포츠인권침해는 계 속된다는 것이다. 이에 문화체육관광부는 기존체제와 차별적으로 스포 츠 인권보호를 강화하기 위해 2차 개정된 국민체육진흥법」('20. 8. 18.
공포) 및 같은 법 시행령, 시행규칙을 2021년 2월 19일(금)부터 다음과 같이 시행한다고 공고하였다(Kim, 2021).

구체적으로 살펴보면 첫 번째, '체육인에게 체육계 인권침해· 비리 즉 시 신고의무를 부과, 신고자·피해자 보호조치 강화'이다. 체육관련자는 체육계 인권침해· 비리를 알게 된 경우나 의심이 있을 경우 스포츠윤리 센터 또는 수사기관에 즉시 신고해야 한다. 신고를 받은 기관은 곧바로 피해자에 대한 긴급보호 조치를 취해야 한다. 두 번째, '직권조사 권한 명시, 조사방해·거부 시 징계 요구 등 조사권 강화'이다. 스포츠윤리센 터가 체육계의 간섭을 배제하고 피신고인 · 단체를 조사할 수 있도록 조 사권한이 강화된 것이다(사건 접수한 날로부터 30 일 내에 조사 착수, 90 일 이내에 사건 처리 등). 세 번째, '가해자에 대한 제재 및 체육계 복귀 제한 강화'이다. 체육지도자가 선수에게 (성)폭력을 가하거나 부정·비 위를 저지른 경우 체육지도자 자격정지 기간을 기존의 최대 1 년에서 최 대 5 년까지로 제재 범위를 확대하였다. 징계정보시스템도 구축해 체육 관련자들의 징계정보를 통합관리 및 활용한다. 네 번째, '상시적 인권침 해 감시 확대 및 체육지도자 등에 대한 인권교육 강화'이다. 매년 체육계 
인권침해 실태조사를 실시하고, 훈련시설 내 CCTV를 설치하며, 비공 식 인력도 체육단체에 등록하도록 하였다. 앞으로 체육지도자는 2년마 다 인권교육을 의무적으로 받아야 한다. 마지막으로 '체육계 표준계약서 도입 및 실업팀 근로감독·운영관리 강화'이다. 실업팀의 경우 계약을 할 때 개발·보급된 표준계약서의 필수 기재사항을 반드시 포함해야 한다. 근로기준법 준수 여부도 문체부에 보고해야 한다(Kim, 2021).

인권(human right)은 보편적으로 인간이면 누구나 당연히 가지는 기 본적 권리를 말한다(Go, 2019). 사전적 정의로는 사람이 개인 또는 나라 의 구성원으로서 마땅히 누리고 행사하는 기본적인 자유와 권리를 의미 한다. 인권 개념과 내용을 논할 때 인권을 인간의 이성 혹은 감성에 기준 을 둘 수 있다. 전자에서는 인간의 인지적 판단능력을 인권존중의 근거 로 삼는다. 인권은 인간이 보편적으로 지향해야 할 도덕적 가치이고, 이 성의 명령을 따라야 인권을 인지하고 인권을 존중하는 판단을 내릴 수 있다는 것이다. 후자에서는 인권의 근거를 인간의 감성에 둔다. 누군가 에게 인권침해를 하는 사람들은 인간의 존엄에 대한 이성적 판단의 결 여가 아니라 그 누군가가 자신과 똑같은 인간이라고 느끼지 않기 때문에 인권침해를 한다는 것이다( $\mathrm{Na}, 2011)$. 이러한 견해들은 선수들이 '어떤 사람도 갖는', '누구나 갖는' 보편적 자연권으로부터 배제되지는 않았는 지, 불평등하게 부여된 보편적 권리성에 의해 불평등과 부정의를 경험하 고 있지는 않은지 등 오늘날 언급되는 스포츠인권을 논할 때 고려해 볼 내용이다.

그동안 역사적, 사회적, 문화적 상황에 따른 운동선수의 인권을 다룬 연구들은 다음과 같이 진행되었다. 첫 번째, 학생선수의 인권실태를 파 악하여 정책분석 및 개선방안의 필요성을 언급한 연구가 있었다. 학습권 보호를 중심으로 스포츠인권 정책분석과 개선방향을 제시한 연구 $(\mathrm{Kim}$ \& Park, 2020), 학생선수의 인권과 일반학생의 학습권보장에 관한 연구 (Kim \& Kim, 2019), 학생선수 인권관련 보도의 프레임 분석에 관한 연 구(Kim, 2010), 학생선수의 안전권 보호정책 실태 및 발전방안에 대한 연구(Kim \& Choe, 2011), 학교운동부 지도자의 스포츠인권신장을 위 한 수행 역할 과제에 대한 연구(Song \& Lee, 2015), 대학에서 학생운동 선수의 삶을 위한 방향에 대한 연구(Lee \& Ahn, 2014) 등이 이에 해당 된다. 둘째, 학생선수들의 인권, 학습권, 진로문제, 역량 증진 등과 문제 를 개선하기 위한 연구가 진행되었다. 학생, 지도자, 학부모를 대상으로 관련 요인을 탐색하고, 전문가 집단을 구성하여 프로그램을 개발하였다 (Jang et al., 2020). 셋째, 선수인권과 법제도를 중심으로 법체계의 특 징과 한계, 개선방안 등을 검토한 연구가 있었다. 학생선수의 학습권에 대한 헌법적 함의에 관한 연구(Kang, 2010), 스포츠 선수의 인권보장을 위한 특별사법경찰관제 도입방안을 제시한 연구(Moon \& Kim, 2020), 스포츠권의 보장을 위한 비교법적 연구(Go, 2019), 스포츠권 법규범 체 계와 국가의 책무에 관한 연구(Yu et al., 2020) 등이 발견되었다. 이와 같이 스포츠인권과 관련된 연구들은 대부분 학교제도권 안에 있는 학생 선수를 대상으로 진행되었다.

그러나 학교제도권 밖에 있는 실업팀 선수를 대상으로 인권침해를 분 석한 연구는 미흡한 실정이다. 최근, Huh et al.(2020)은 실업팀 직장운 동선수를 대상으로 인권침해 실태를 분석하였다. 실업팀 직장운동선수 는 성인선수임에도 불구하고 운동부 생활과 합숙소에서 생활통제가 심 했다. 언어적 신체적 폭력 등의 인권침해는 광범위하게 나타났으며 성 희롱, 성폭력 등의 인권침해도 적지 않게 발생하고 있었다. 주요 가해자 는 지도자와 선배였고 장소는 훈련장이었다. 선수들은 위계적, 집단적인 분위기와 개인적 불이익 등이 두려워 소극적으로 대처할 수밖에 없는 환 경에 처해있었고, 계약과 처우 등에서 노동인권 사각지대임이 나타났다
(Huh et al., 2020). 이 연구는 직장운동선수들이 인권침해에 매우 취약 한 환경에 놓여있음을 설명하였다. 하지만 양적 설문으로만 수행되어 선 수들이 경험하는 인권침해 경험이 구체적으로 어떻게 나타나는지에 대 한 상세한 정보는 제공되지 못하고 있다.

실업팀 직장운동선수에 대한 인권침해 연구는 스포츠윤리를 넘어 인 권적 관념에서 다음과 같이 몇 가지 측면을 주목해야 한다. 첫 번째, 전 반적으로 선수들의 인권침해가 가장 많이 발생하는 장소는 합숙소인데, 합숙소 생활을 가장 많이 경험하는 시기는 실업팀(86.4\%)으로 나타났 다(Huh et al., 2020). 초중고 시절부터 이어졌을 폭력피해에 실업팀 직 장운동선수들은 심리적으로 학습된 무기력을 가장 많이 경험하고 있을 것이다. 두 번째, 실업팀 직장운동선수는 「근로기준법」적용 대상이지 만 법적인 권리에 제약이 많고, 신분보장도 어려운 실정이다. 현실적으 로 지원의 사각지대에 놓여있는 실업팀 직장운동선수들은 현실적으로 많은 인권문제에 노출되어 있을 것이다. 세 번째, 반복되는 부당한 폭력 상황에 내성이 형성된 실업팀 직장운동선수는 부지불식간에 피해자에 서 가해를 재생산하는 지위 즉, 지도자 위치에 설 수 있다는 점을 인식 해야 한다.

따라서 본 연구는 실업팀 직장운동선수들이 경험하는 인권침해라는 현상의 본질을 파악하고, 그에 대한 사례를 탐색하는데 목적을 두었다. 실업팀 직장운동선수가 겪는 인권침해 경험은 Colaizzi(1978) 현상학적 연구방법(phenomenological method)을 활용하여 분석하였다. 이 방 법은 수집된 자료를 통한 기술적 차원의 파악과 함께 경험의 함축적인 구조의 차원까지 파악할 수 있다는 장점이 있다(Lee, 2014). 또한 개인 의 상황이나 개별성과 같은 특성보다는 공통성에 치중하는 방법(Han \& Yoon, 2020)이라는 점에서 인권침해의 공통적 현상을 찾는데 더욱 확 실한 방법이라고 할 수 있다.

이러한 방법은 실업팀 직장운동선수의 인권침해의 경험에 내재하여 있는 함축적인 구조를 파악하여 선수의 인권침해 경험을 이해하도록 도 움을 줄 것이다. 향후 실업팀 직장운동선수들의 인권보호에 실제적인 도 움을 줄 수 있는 지침서의 기틀을 마련하고, 실업팀 직장운동부에 대한 사회적 시각을 긍정적으로 전환할 수 있는 기초자료로 활용할 수 있을 것이다.

\section{연구방법}

\section{연구참여자}

본 연구는 연구목적을 달성하기 위해 의도적 표집방법을 사용하였다. 연 구참여자 선정기준은 현재 실업팀에 소속되어 있는 선수였다. 연구의 범 위가 실업팀에 소속되어 있는 중에 발생하는 선수의 인권침해 경험을 다 루기 때문에 신뢰성을 확보하고자 퇴사한 선수는 연구참여자에서 제외 하였다. 연구참여자는 실업팀 직장운동선수 인권 실태조사(2019)와 관 련하여 자발적으로 상담요청을 한 선수 중 인터뷰를 수락한 이들로 총 35명(17팀)이었다.

연구참여자의 연령은 20 39세이고, 선수 경력은 9 29년으로 나타났 다. 종목은 개인종목과 단체종목을 모두 포함하여 컬링, 육상(마라톤), 요트, 축구, 우슈, 사이클, 역도, 펜싱, 육상(멀리뛰기), 태권도, 카누, 하 키, 스키(모굴스키), 체조, 빙상 등 15 개 종목이다. 연구참여자의 개인적 특성은 〈Table 1)과 같다. 본 연구에서 다루는 인권침해 경험은 연구참 여자에게 민감한 부분이므로 선수의 신상을 유추할 수 있는 구체적인 나 이와 경력은 기재하지 않았다. 
Table 1. Characteristics of participants

\begin{tabular}{ccc}
\hline & Gender(N) & Event \\
\hline A & F(4) & Curling \\
B & M(1) & Marathon \\
C & M(1) & Yacht \\
D & $\mathrm{F}(3)$ & Soccer \\
E & M(1) & Wushu \\
F & $\mathrm{M}(1)$ & Cycle \\
G & $\mathrm{M}(1)$ & Weightlifting \\
H & $\mathrm{F}(1)$ & Fencing \\
I & $\mathrm{M}(1)$ & Marathon \\
J & $\mathrm{M}(1)$ & Long Jump \\
K & $\mathrm{M}(1)$ & Taekwondo \\
L & $\mathrm{M}(4)$ & Canoe \\
M & $\mathrm{F}(3)$ & Soccer \\
N & $\mathrm{M}(1)$ & Hockey \\
O & $\mathrm{F}(1)$ & Mogul ski \\
P & $\mathrm{F}(3)$ & Gymnastics \\
Q & $\mathrm{M}(7)$ & Ice skating \\
\hline
\end{tabular}

\section{자료수집}

본 연구는 연구참여자를 대상으로 한 심층면담 및 FGI(Focus Group Interview)를 통해 자료를 수집하였다. 2019년 7월부터 8월에 걸쳐 실 시하였다. 먼저, 반구조화된 질문지를 제작하였다. 반구조화된 질문지 의 영역들은 문헌연구를 통해 작성되었다. 전문가 자문회의를 통해서 그 적합성과 타당성을 검토한 후 수정 보완하여 확정하였다. 인권침해 경 험을 심층적으로 검토하기 위한 반구조화된 질문의 내용은 다음과 같다. '실업팀 직장운동선수의 고용형태 및 계약관계에 대해 얼마나 알고 있나 요?', '인권침해 경험 이후 어떤 생각이 들었나요?', '인권침해 경험 이후 어떤 감정을 느겼나요?, '인권침해 문제해결을 위해 어떤 행동을 했나 요?', '실업팀 직장운동선수들의 인권보호 지원시스템에 얼마나 만족하 나요?' 등 이었다.

면담은 반구조화된 질문지를 바탕으로 진행하였다. 의미 있는 정보에 대해 연구참여자가 자신의 경험을 주어진 형식에 얽매이지 않고 자유롭 게 이야기할 수 있도록 하였다. 연구참여자가 자신의 가치관, 생각, 경 험, 그리고 행동 등에 대해 충분히 설명하여 연구현상에 대한 자료가 확 보될 때까지 자료를 수집하였다. 면담은 1 회당 1 시간 30 분에서 2 시간 정도 소요되었다. 면담내용은 연구참여자의 동의를 거쳐 휴대용 녹음기 (IVR-10) 및 스마트폰의 녹음기능을 사용하여 저장하였다.

\section{자료분석}

본 연구는 질적연구방법의 한 유형인 현상학적 방법(phenomenological method)을 활용하여 자료를 분석하였다. 본 연구에서 이 방법을 활 용한 이유는 실업팀 직장운동선수들의 주관적 경험과 함축적 의미를 깊 이 있게 이해하기 위해서이다. Colaizzi(1978)의 방법을 토대로 다음과 분석하였다(〈Table 2〉 참조). 1) 친밀하게 자료를 검토: 연구참여자와의
Table 2. Steps in Colaizzi's descriptive phenomenological method

\begin{tabular}{ll}
\hline & \multicolumn{1}{c}{ Step } \\
\hline 1 & Familiarisation \\
2 & Identifying significant statements \\
3 & Formulating meanings \\
4 & Clustering themes \\
5 & Developing an exhaustive description \\
6 & Producing the fundamental structure \\
7 & Seeking verification of the fundamental structure \\
\hline
\end{tabular}

녹음자료를 반복해서 들으면서 그대로 전사하였다. 면담 내용의 생생한 느낌을 살리기 위하여 내용의 전사는 면담 당일에 시작하여 3 일 안에 완 료하였다. 각 참여자에게 그 내용이 제대로 기술되었는지 확인하였다. 의문 사항이 있거나 부가 질문이 필요한 경우 추가 면담을 통해 자료를 보완하였다. 2) 중요한 진술을 도출: 전사한 내용을 수차례에 걸쳐 읽으 면서 본 연구의 현상과 내용에 대하여 이해하고, 의미있는 진술을 파악 하였다. 3) 의미 형성: 의미있는 진술에 해당하는 문장들을 검토한 후 형 성된 의미를 도출하였다. 4) 주제 모음: 형성된 의미에서 주제(themes), 주제 모음(theme clusters), 범주(categories)로 구조화하였다. 5) 철저 한 기술 개발: 지금까지 분석된 자료를 주제에 따라 철저하게 기술하였 다. 6) 기본 구조 생성: 선행단계에서 확인된 실업팀 직장운동선수의 경 험에 대한 공통적인 요소를 통합하여 본질적인 구조를 파악하였다. 7) 기본 구조의 타당도 검증: 본질적인 구조에 대한 타당성을 확인하기 위 해 연구참여자에게 자신들이 표현하고자 했던 의미나 경험이 일치하는 지를 확인하였다. 이러한 일련의 과정으로 실업팀 직장운동선수의 인 권침해 경험에 대한 공통적이고 중요한 특성을 도출하였다(Morrow et al., 2015).

\section{연구의 윤리성 및 엄격성 확보}

본 연구의 윤리성을 확보하기 위해 자율적인 참여가 이루어지도록 하였 다. 연구자는 면담 전에 연구참여자들에게 연구목적과 절차에 대해 충분 히 설명하고 참여에 대한 동의를 구하였다. 연구 참여 동의서를 통하여 면담 내용의 녹음 처리, 비밀 유지를 위한 익명 처리, 자료의 사용범위, 연구 참여 중단의 권리 등을 다시 한번 알려주고 서명을 받았다.

또한 연구의 신뢰도 및 타당도를 확보하고자 Lincoln \& Guba(1985) 의 엄격성 평가기준을 높일 수 있도록 노력하였다. 내적타당도에 해당하 는 사실적 가치(truth value)를 확보하기 위하여 분석 결과가 진술 내용 과 일치하는지 연구참여자에게 대면 혹은 전화로 확인을 받았다. 외적타 당도에 해당하는 적용성(applicability)을 확보하기 위하여 연구자는 연 구목적을 달성할 수 있을 정도의 충분한 자료를 수집하였고, 참여자로 포함되지 않은 다른 실업팀에 근무하는 선수에게 연구 결과의 검토를 의 뢰하였으며, 이들이 연구 결과에 공감하는 것을 확인하였다. 신뢰도에 해당하는 일관성(consistency)을 확보하기 위하여 스포츠심리학 교수 1 인과 스포츠인권전문가 1 인에게 연구 논제, 구성, 자료분석, 결과 등을 검증받았다. 객관성에 해당하는 중립성(neutraility)을 확보하기 위하여 참여자의 진술을 수집 및 분석하는 과정에서 편견이 개입되거나 자의적 으로 해석하지 않도록 수시로 체크를 하였다. 


\section{연구결과}

본 연구는 실업팀 직장운동선수들이 경험하는 인권침해 현상의 본질을 파악하고, 그에 대한 사례를 탐색하는데 목적을 두었다. 실업팀 직장운 동선수 인권침해 경험을 분석한 결과, 최종적으로 5 개 범주, 14 개의 주 제 모음, 41 개의 주제가 도출되었다(〈Table 3〉 참조).

\section{1. 실업팀 선수가 되는 첫걸음: 불합리한 선수계약}

실업팀 선수가 되는 첫걸음은 불합리한 선수계약 경험이었다고 선수들 은 언급했다. '선수 의견이 무시된 계약', '지나친 경기성적 압박', '소속 팀 위주로 바뀌는 재계약서’ 등 세 개의 주제모음이 나타났다.

\section{1) 선수 의견이 무시된 계약}

실업팀에서 선수 의견을 배제하고 지도자들끼리 계약 내용을 결정하 거나, 다른 팀으로 갈 수 없도록 계약날짜를 최대한 미루거나, 계약 당일 구두계약과 다른 조건을 제시하며 다운계약을 하는 것으로 나타났다. 입 사 후 예상보다 월급이 적게 입금되기도 한다고 언급하였다.

\section{“근로계약서가 뭐에요? 전 제대로 본 적이 없는데요. 아마 제 계약서는 감독 님이 가지고 계실 거에요. 다른 선수들 계약서랑 같이 모아놓았다고 들은 것 같아요." (연구참여자 I) \\ "월급이 예상보다 적게 입금됐더라고요. 훈련 끝나고 건의를 했죠. 감독이 하 는 말이 선수를 스카우트할 때 선수한테 거짓말을 해서 이렇게 할 수 있는 거래요. 감독이 '실업연맹법으로 하자, 변호사 섭외하자' 이렇게 강하게 나}

Table 3. Results

\begin{tabular}{|c|c|c|}
\hline Category & Theme clusters & Themes \\
\hline \multirow{3}{*}{$\begin{array}{l}\text { The first step } \\
\text { to becoming } \\
\text { a semi- } \\
\text { professional } \\
\text { athlete team } \\
\text { member }\end{array}$} & $\begin{array}{l}\text { Entering a contract without reflecting } \\
\text { the athlete party's opinions }\end{array}$ & $\begin{array}{l}\text { - The terms and conditions of the contract are decided by and between the coaches of each party } \\
\text { - Postponing the execution date of the contract as much as possible } \\
\text { - Other terms and conditions are offered at the signing date of the contract and/or at a dropped price } \\
\text { - Salary paid less than expected after joining the company }\end{array}$ \\
\hline & $\begin{array}{l}\text { Too much pressure on } \\
\text { match performance }\end{array}$ & $\begin{array}{l}\text { - Pressures on a good performance for coaches and local governments } \\
\text { - Cannot use annual leave in case of losing games because the players are blamed for the failure } \\
\text { - Risk of injuries due to frequent competitions, neglected pains, and concerns about medical expenses } \\
\text { - Intentional waiver of performance by athletes }\end{array}$ \\
\hline & $\begin{array}{c}\text { Changes in the terms and conditions } \\
\text { of the contract focusing on } \\
\text { the team in case of renewal }\end{array}$ & $\begin{array}{l}\text { - No prior notice on the renewal of the contract and unilateral suspension of the contract } \\
\text { - Different ways of renewal depending on each team }\end{array}$ \\
\hline \multirow{3}{*}{$\begin{array}{l}\text { Unavoidable } \\
\text { absolute power }\end{array}$} & Coaches' verbal and physical violence & $\begin{array}{l}\text { - Verbal violence in a way that undermines personality } \\
\text { - Explosive anger throwing things } \\
\text { - Lack of leadership qualities }\end{array}$ \\
\hline & Abuse of leadership authority & $\begin{array}{l}\text { - Excessive sense of authority } \\
\text { - Unguaranteed right to know training schedules } \\
\text { - Lack of expertise in sports and delaying applications for competitions }\end{array}$ \\
\hline & $\begin{array}{l}\text { Isolation of human relations due to } \\
\text { conflicts with coaches }\end{array}$ & $\begin{array}{l}\text { - Disrupting the career path by gossiping about the athletes and damaging their reputation } \\
\text { - Athletes trying to read the mind of their coaches } \\
\text { - Cold reactions of the people surrounding the athletes, depression, and suicide attempts }\end{array}$ \\
\hline \multirow{3}{*}{$\begin{array}{l}\text { Compulsory } \\
\text { living in a } \\
\text { training camp }\end{array}$} & $\begin{array}{l}\text { Controlling autonomy with internal } \\
\text { guidelines }\end{array}$ & $\begin{array}{l}\text { - Dormitory life restricted from going out or staying out } \\
\text { - Strict adherence to accommodation rules and excessive penalty for violations } \\
\text { - Sharing a house with coaches }\end{array}$ \\
\hline & $\begin{array}{l}\text { Infringement of privacy during } \\
\text { non-exercise hours }\end{array}$ & $\begin{array}{l}\text { - Forced socializing activities from dining to karaoke together. } \\
\text { - Mobilized for weekend events and forced to give lessons to acquaintances }\end{array}$ \\
\hline & Hierarchical culture according to age & $\begin{array}{l}\text { - Insufficient rest space due to sharing the same space with elder athletes } \\
\text { - Chores handled by younger athletes due to poor environment }\end{array}$ \\
\hline \multirow{2}{*}{$\begin{array}{l}\text { The structural } \\
\text { problem of } \\
\text { the Federation } \\
\text { of Semi- } \\
\text { professional } \\
\text { Athletes } \\
\text { Association }\end{array}$} & $\begin{array}{l}\text { Concerns about disadvantages and } \\
\text { secondary damage of stigma in case } \\
\text { of raising complaint }\end{array}$ & $\begin{array}{l}\text { - Raising a complaint means putting a tag on the athlete } \\
\text { - Concerns over team dissolution and a sense of crisis in athlete life in case of raising an issue } \\
\text { - Learned helplessness }\end{array}$ \\
\hline & $\begin{array}{l}\text { Difficulty in publicizing issues } \\
\text { on the Federation }\end{array}$ & $\begin{array}{l}\text { - No transfer market for athletes due to uniform legal use } \\
\text { - Forcing to make a statement coercively in the event of a transfer. } \\
\text { - Support systems only focusing on the top player, and ignorance of unpopular sports, etc. } \\
\text { - Military service issues for male athletes. }\end{array}$ \\
\hline \multirow{3}{*}{$\begin{array}{l}\text { Experiencing } \\
\text { gender } \\
\text { discrimination } \\
\text { in a male- } \\
\text { centered sports } \\
\text { environment. }\end{array}$} & $\begin{array}{l}\text { The precarious athletic environment } \\
\text { of female athletes }\end{array}$ & $\begin{array}{l}\text { - Giving up communication with male coaches on the menstrual cycle. } \\
\text { - More serious performance pressure and gender discriminative words than male athletes. } \\
\text { - Sexual harassment by coaches and male elder athletes } \\
\text { - Forced participation in a drinking party with coaches and coercive introduction of acquaintances }\end{array}$ \\
\hline & $\begin{array}{l}\text { Continuing difficulties in marriage, } \\
\text { pregnancy, and childbirth }\end{array}$ & $\begin{array}{l}\text { - Exclusion from selection due to marriage and pregnancy plans. } \\
\text { - Difficulties in the balance between parenting and athletic life. }\end{array}$ \\
\hline & $\begin{array}{l}\text { A glass ceiling hard to break } \\
\text { through for a female coach }\end{array}$ & $\begin{array}{l}\text { - A small pool of female athletes and narrow path for a leadership career. } \\
\text { - It is hard for female coaches to get promoted to a higher rank. }\end{array}$ \\
\hline
\end{tabular}


오더라고요. 이 감독이 저한테만 이렇게 한 게 아니라 지금까지 여러 명의 선수들에게 다 그렇게 했어요." (연구참여자 J)

"계약은 고등학교 때 감독 선생님이 해주셨어요. 제가 신경 썼던 부분은 거의 없어요. 고등학교에서 바로 이 팀으로 왔고, 감독 선생님들끼리 계약 내용을 이야기했어요. 저는 어디로 오라고 해서 갔고, 감독님이 계약서에 싸인하라 고 해서 시키는 대로 했죠." (연구참여자 P1)

"감독이 좋은 선수를 데리고 오려고 장난을 좀 많이 쳐요. 선수에게 금액을 많이 준다고 솔깃하게 만들고, 12월까지 계약날짜를 계속 늦춰요. 다른 팀 들이 보통 11 월 중순에 계약을 다 하니까, 나중에는 갈 곳이 없으니 어쩔 수 없이 계약하죠." (연구참여자 J)

"계약서를 쓰는 날이 됐는데요. 처음 이야기한 것과 조건이 달랐어요. 금액까 지도요. 저는 이렇게 조건을 맞춰준다고 해서 왔는데요. 라고 말하니 감독이 화를 내면서 막 욕을 하는 거예요." (연구참여자, B)

\section{2) 지나친 경기성적 압박}

지나친 경기성적 압박에서는 선수 육성이 아닌 지도자/지자체 실적을 위해 성과압박을 하거나, 시합에서 지면 선수 탓이니 눈치가 보여서 연 차를 쓸 수 없다고 했다. 또한 인권침해로 인한 선수의 신체적 피해도 나 타났다. 잦은 시합으로 인해 부상에 시달리고, 심한 통증을 지도자에게 호소해도 무시당한다고 언급했다. 부상 및 재활치료비를 선수 자비로 해 결하는 상황이다 보니 몸보다 치료비 걱정을 하고 있었다. 컨디션 조절 을 위해 의도적으로 성과를 포기하는 모습도 나타났다.

"회사나 감독 입장에서는 선수가 일단 성적을 내야 해요. 그래서 선수한테 성 질내고 욕하고 닦달하는 거죠. 선수 육성이 아니라 선수들이 성적 냈을 때 본인에게 얼마가 돌아오고 뒤에 따라오는 게 많으니까요. 도민체육대회같은 조그만 대회라도 나가서 1 등을 해야 해요. 선수들은 강제로 뛰는 거죠. 감독 이나 시군청은 선수를 이용해서 이득을 보고, 실적을 올릴 생각만 하죠. 선 수는 이용만 당하다가 인생이 끝나는 거죠." (연구참여자 $\mathrm{G}$ )

"지면 선수탓을 하죠. 지면 저희한테 전화해서 막 욕해요. 법정휴가요?! 저는 작년까지 연차도 제대로 못 썼어요. 너무 억울한 거에요. 대표님 아닌 애들 은 국내 대회만 뛰면 되지만 국제대회도 소화하면 너무 많이 쉬고 싶잖아요. 대표님 일정 없을 때는 팀으로 돌아오는데요. 연차 쓰고 싶다고 선생님한테 말씀드리면 엄청 뭐라고 하니까요. 너무 쉬고싶은데 눈치가 보여서 계속 연 차를 못 썼어요." (연구참여자 $\mathrm{A} 1$ )

"잦은 시합에서 성적을 내려면 선수의 운동량이 많아지죠. 전 몸이 만신창이가 됐어요. 감독에게 아프다고 말하면 감독은 오히려 무시해버려요. 네가 뭘 아 파 그냥 해. 부상인데도 경기를 뛰라고 해요. 팀을 위해서 선수 생활을 했는데 지금 저한테 남은 게 병밖에 없어요. 만성통증이라 돈도 많이 들어요. 아프면 내 돈으로 치료해야 하니 몸보다 돈 걱정이죠. 은퇴하고 나서가 더 문제예요. 부상 후유증으로 계속 몸이 아플텐데 어떡하나 걱정이 되죠." (연구참여자 O)

"시합 뛰다가 컨디션이 안 좋으면 에이 지고 말아야지 이런 식으로 해버려요. 실업팀은 프로니까 최선을 다해야 하는데요. 그런 것들까지 없어지는 거죠. 또 감독한테 선수들이 말이나 행동으로 대들 수 없는 분위기이니까요. 성적 으로 복수하는 거죠. 성적이 안 나오면 감독 입장이 난감해지니까요." (연구 참여자 $\mathrm{K})$

\section{3) 소속팀 위주로 바뀌는 재계약서}

선수들은 실업팀의 계약서 내용이 처음과 다르게 점차 회사 위주로 바 뀌고 있다고 했다. 회사가 피해를 안 보기 위해 선수에게 피해를 전가한 다는 것이다. 선수들은 재계약 여부를 미리 고지받지도 못하고, 일방적 으로 혹은 반강제적으로 소속팀을 나가게 되기도 하는데, 팀별로 재계약
방식이 다 달라서 더 힘들다고 언급했다.

"재계약을 하는 해에는 걱정을 많이 하죠. 죽을힘을 다해서 시합에 모든 걸 걸어요. 재계약 기간에 한 번 못 했다고 계약기간을 줄인다거나 연봉을 많이 깎는다거나 그러니까요. 선배 형은 다른 곳과 재계약을 할 수 없는 상황에서 갑자기 잘렸어요. 전국체전 일주일 전에 다른 팀을 알아보라고 했대요. 이미 다른 팀들은 티오를 다 갖췄는데, 그때 선수를 퇴출 시키는 건 선수보고 죽 으라는 거죠." (연구참여자 L1)

"기준이 팀마다 다 달라요. 재계약 평가 기준은 잘 몰라요. 그냥 합숙 생활을 하니까 선배들한테 자연스럽게 듣는 거죠. 성적이나 메달 색깔, 순위별로 해 서 연봉이 달라지는 것 같기도 해요." (연구참여자 Q1)

\section{2. 피할 수 없는 절대권력자: 코치, 감독에게 복종}

선수들은 피할 수 없는 절대권력자인 코치, 감독에게 복종한 경험을 호 소했다. '지도자의 언어 및 신체적 폭력', '지도자 권한 남용', '지도자와 의 불화로 인한 인간관계 고립' 등 세 개의 주제모음이 나타났다.

\section{1) 지도자의 언어 및 신체적 폭력}

선수들은 지도자의 폭언 및 폭행으로 인한 인권침해를 경험하고 있었 다. 지도자가 선수의 인격을 깎아내리는 방식의 언어폭력을 하거나, 자 신의 화풀이로 선수에게 물건을 던지거나, 리더의 자질조차 부족한 모습 을 언급했다.

“말로 선수한테 엄청 수치심을 줘요. 이만큼 너희한테 지원해주는데 이거 못 하면 병신이지. 어디 가서 이 연봉 받고 일했겠냐? 우리니까 너희가 이 정도 연봉 받으면서 일하는 거다. 너희가 어디 가서 이런 대접을 받겠냐? 애들은 정신이 쓰레기네... 선수를 그냥 쓰고 버리는 물건으로 생각해요. 데려왔는 데 실적을 못 내면 자르면 그만이지. 야! 너 이리로 와, 이 새끼, 이년아, 글 러빠진 새끼야. 이런 식으로 막말을 하세요. 이런 표현을 하는 것 자체가 말 이 안 되는 거죠." (연구참여자 A2)

"이야기하다가 물건을 집어 던지는 거예요. 물건을 바닥으로 막 던져요. 나가 라고 소리를 지르고요. 제 인생동안 받지 못했던 모욕감을 느겼어요. 자존심 이 많이 상했죠." (연구참여자 N)

“감독으로서 자질이 부족하세요. 자신감만 좋으세요. 감독님은 무조건 자기 말만 들으라고 해요. 대표팀에서 배웠던 걸 팀에서 하면 마음에 안 들어 해 요. 시합에 지고 있으면, 저희를 인솔해야 하는 사람이 삐져서 숙소로 가버 려요." (연구참여자 $\mathrm{M} 1$ )

\section{2) 지도자 권한 남용}

실업팀에서 지도자의 권한이 남용되고 있었다. 선수를 자르거나, 선수 병원비를 지급하거나, 연봉을 올려주는 일들이 감독 고유의 권한이라고 생색을 내며 선수를 좌지우지한다고 언급했다. 또한 지도자가 지나친 권 위 의식으로 훈련스케줄을 선수에게 미리 알려주지도 않고, 종목에 대한 전문성 부족으로 시합 신청을 놓치는 것으로 나타났다.

"감독, 코치는 선수가 고개 숙이기만 바라죠. 무조건 갑과 을이에요. 내가 말 하면 들어. 이래요. 선수는 시키는 걸 하는 게 당연하다. 이렇게 생각하죠. 지도자들은 선수에게 예의만 요구하는데요. 힘든 건 그 예의라고 요구하는 것들이 지도자마다 다 달라요." (연구참여자 F)

"예전부터 저희는 항상 일정을 알 수가 없었어요. 주말에는 원래 쉬는 건데, 감독님이 이번 주말에 훈련해야 한다. 이런 식이어서요. 그래서 한 달 치를 
미리 알려달라 하니까 상황이 안 돼서 알 수가 없다고 해요. 휴식해야 하는 데 쉬는 동안에도 갑자기 부르는 경우가 많아서요. 쉬면서도 불안한 경우가 많았어요." (연구참여자 D2)

"훈련 방법도 잘 모르시면서 공부를 안 해요. 공부하는 선수가 필요하듯이 공 부하는 지도자가 필요하잖아요. SNS, 유튜브, 영상매체를 보면서 선수에게 이런 훈련도 접목해 볼 수 있겠구나. 이래야 하는 것 아니에요. 기술에 대해 디테일하게 지도자로서 짚어줄 수 있어야죠. 거기다 시합을 나가고 싶은데 시합 신청을 안 해줘요. 전화해도 안 받고, 문자를 보내도 답장이 안 와요. 뭐가 그렇게 바쁜지 왜 시합 신청을 미루는지 모르겠어요." (연구참여자 J)

\section{3) 지도자와의 불화로 인한 인간관계 고립}

선수들은 감독과의 갈등 이후 솔직하게 힘든 점을 감독에게 이야기했 다가 오히려 동료와의 관계가 고립되었다고 한다. 이후 감독이 선수를 험담하며 평판을 떨어뜨려서 진로를 방해했다고 언급했다. 코치-감독 간의 갈등으로 그 사이에서 선수가 곤란한 상황도 나타났다. 선수들은 주변의 차가운 시선에 우울증을 경험하고 있었고, 심지어 자살을 시도한 선수도 있었다.

\begin{abstract}
"감독님이 제 소문을 안 좋게 내는 거예요. 다른 시군청 감독들한테 안 좋은 이미지를 심어주려 한 것 같아요. 팀 욕을 하고 다닌다. 감독 욕을 하고 다닌 다. 본인 덕분에 제가 이만큼 잘 됐는데 배은망덕하다. 이런 식으로요. 그만 큼 제가 맘에 안 든다는 거죠. 넌 운동 안 하면 먹고 살 수가 없다. 지도자의 협박성 멘트!! 이런 거 금지해야 해요. 이것만 열심히 했기 때문에 다른 일을 생각하면 선수는 앞이 막막하죠. 저한테 실업팀 콜이 한 6 개가 들어왔어요. 그런데 제 상의 없이 다 자르신 거예요." (연구참여자, M3)

"감독과 코치 간 갈등이 있었어요. 감독님은 코치님과 아예 말을 안 섞었어요. 감독님이 저희한테도 코치님과 그냥 이야기하지 말라고 하셨고요. 분위기가 그러니 눈치만 보는 이상한 분위기였죠." (연구참여자 $\mathrm{N}$ )

"주변 사람들 반응이 좀 그랬죠. 팀 선배에게 힘든 이야기를 하면 내 탓이래 요. 동갑내기 친구도 저에게 그만두래요. 기댈 곳이 없어요. 전 어머니 앞에 서 감독한테 맞았어요. 엄마도 운동선수였거든요. 우리 어머니는 더 맞아야 한다고. 재는 맞아야 정신 차린다고. 그냥 그때부터 스트레스 때문에 우울증 이 심했죠. 선수들은 자기 탓을 많이 하죠. 내가 잘못했네. 상담을 받아보면 제 탓이 아닌 거예요. 선수들은 본인이 우울증인 걸 몰라요. 그냥 내 정신력 이 약하다. 이겨내야지. 극복해야지. 이렇게 생각해요. 저도 우울증인 거 몰 랐는데요. 심리상담을 하면서 제가 우울증인 걸 알았거든요. 전 소속팀에서 자살 시도를 했었어요. 최근에도 감독과의 갈등 이후 다시 자살 시도를 했었 고요." (연구참여자, $\mathrm{B}$ )
\end{abstract}

\section{3. 강제 합숙소생활: 자율성 및 사생활 침해}

강제 합숙소 생활로 선수들은 자율성 및 사생활 침해를 경험하고 있었 다. '내부지침으로 자율성 통제', '운동시간 외 사생활 침해', '위계적 선 후배 문화' 등 세 개의 주제모음이 나타났다.

\section{1) 내부지침으로 자율성 통제}

선수들은 내부지침으로 자율성이 통제되고 있었다. 주중은 물론 주말 까지 외출 외박이 통제된 숙소 생활을 하고 있었다. 정해진 숙소 규칙을 엄수해야 하고 위반 시 과다한 벌금도 내야 했다. 선수들은 지도자와 숙 소를 같이 사용하다 보니 눈치가 보여서 자유롭게 행동할 수가 없다고 언급했다.

\footnotetext{
"숙소에 있으니 밤에 외출을 마음대로 못 하죠. 점호시간이 있고요. 저녁 10
}

시 이후에는 밖으로 나가본 적이 없어요. 전에 있던 곳에서는 감독이 밖에도 잘 못 나가게 해서 교도소처럼 생활했어요. 시합 기간이 다가오면 훈련이 있 으니까 주말에도 못 나가요." (연구참여자 $\mathrm{E}$ )

"합숙소 생활에서 규칙을 꼭 지켜야 해요. 규칙을 어기면 벌금을 내야 하죠. 작은 잘못은 십만 원, 폭력이나 무단 이탈 그런 거는 백만 원이요. 숙소 내 음식물은 반입금지요." (연구참여자 $\mathrm{M} 3$ )

"숙소에 지도자와 같이 살면 방이 분리되어 있어도 선수들은 엄청 싫고, 불편 하죠. 아무래도 자유롭지 못하니까요. 숙소에 코치님 감독님이 있으면 아예 거실조차 안 나오고 방에만 있어요. 주말 개인 시간에 밖에 나가려 해도 눈 치가 보이죠. 그때 운동을 개인적으로 안 하면 뭐라 하시는 분도 있었어요. 스케줄을 짜서 주말에도 운동시킬 거라고 했던 분도 있었고요. 아무래도 선 수들은 힘들죠." (연구참여자 $\mathrm{M} 1$ )

\section{2) 운동시간 외 사생활 침해}

선수들은 사생활을 침해당하고 있었다. 미리 통보 없는 회식이 잦았 다. 회식에서 식사가 끝나도 지도자가 일어날 때까지 자리를 지켜야 했 다. 회식이 2차 노래방까지 이어져서 밤늦은 시간까지 잡혀있는 것으로 나타났다. 주말에 지도자의 사적 업무에 동원되거나, 지도자 지인의 레 슨을 해야 했다.

“미리 통보도 없이, 갑자기 감독이 오늘 회식 있다 나와라 이래요. 제가 약속 이 있어도 어쩔 수 없이 취소하고 회식에 참석하죠. 감독이 거의 한 달에 한 번은 회식을 해요. 자기가 끝나야 회식이 끝나는 사람이라서 힘들죠. 회식에 가면 먹기 싫은 술을 먹어야 하고, 2 차로 노래방을 가요. 밤 12 시가 넘어가 도 무조건 따라와라 이래요. 심지어 전지훈련을 9 박 10 일을 가는데 그 기간 에는 회식을 더 많이 해요. 훈련하러 가는데 밤늦게까지 쉬지를 못하니까 힘 들죠. 회식 다음 날 피곤한 상태로 운동해야 하니 선수들의 불만이 굉장히 높 죠." (연구참여자 P2)

"그냥 그날 시간을 비워두라고 해서 갔는데요. 유치원 운동회 행사였어요. 자 기 아들 유치원 행사에서 싸인하라고... 지인들 레슨하라고... 쉬는 날이어도 무조건 나가서 해줘요." (연구참여자 A3)

\section{3) 위계적 선후배 문화}

선수들은 암암리에 정해진 위계적 선후배 문화로 힘들어하고 있었다. 선배와 같은 공간을 사용하다 보니 개인공간은 물론 휴식 공간마저 부족 했다고 언급했다. 숙소에서는 열악한 환경으로 식사부터 설거지, 빨래, 청소, 잔심부름 등 집안일을 도맡아서 하고, 훈련장에서는 필요한 운동 용품을 후배가 전담해서 챙기는 것으로 나타났다.

"전에는 화장실을 가려면 다 거쳐서 가야 할 정도로 진짜 좁은 숙소였어요. 문 열 때도 소리 안 나게 조용히 열어야 했죠. 방 하나에 2층 침대 2개 놓고, 4 명이 생활했어요. 제 공간은 없죠... 특히 언니들이랑 쓰는 게 진짜 불편했죠. 팀에 너무 무서운 언니들이 있거든요. 아무 때나 맘대로 방을 막 휘젓고 다니 기도 해요. 갑자기 서랍장 같은 거 열어보면서 옷 정리를 안 하나? 서랍장에 서류 같은 거 보면서 누가 뭐 했냐? 선배 노릇을 하죠. 언니들이랑 한 공간에 같이 있는 게 아직도 조금 어색해요. 초반에는 더 그랬어요. 휴식이요?! TV도 못 봤어요." (연구참여자 P3)

"선배가 왕이니 식사는 당연히 후배 담당이죠. 거기다 설거지, 청소, 잔심부름 등 숙소 집안일을 도맡아서 해요. 가장 중요한 건 빨래요. 빨래 너는 것도 힘 든데 마르면 개어서 옷장에 넣어줘야 해요. 훈련장에서도 운동이나 마크, 혼 등 운동용품을 챙겨야 해요. 숙소 창고에 있는 것을 훈련장으로 가지고 가고, 훈련은 끝나면 제자리에 돌려놓고. 이런 기구들을 잘 못 챙기면 혼나죠." (연 구참여자 $\mathrm{M} 2)$ 


\section{4. 실업연맹의 구조적 문제: 힘을 가진 자의 횡포}

실업연맹의 구조적인 문제로 선수들은 힘을 가진 자의 횡포를 경험하고 있었다. '문제제기시 불이익 및 낙인의 2차 피해 우려', '연맹문제 공론 화의 어려움' 등 두 개의 주제모음이 나타났다.

\section{1) 문제제기시 불이익 및 낙인의 2 차 피해 우려}

선수들은 혹시나 본인이 문제를 제기하면, 그것이 평생 자신의 꼬리표 로 붙어 다닐 거라고 인식하고 있었다. 또한 문제가 일어난 팀을 해체해 버리는 사례를 직접 보고 나니, 직장을 잃게 될 거라는 불안감에 신고를 꺼리는 것으로 나타났다. 감당하기 힘든 스트레스를 호소해도 달라지지 않는 상황에 선수들은 학습된 무기력을 경험하고 있었다.

"같은 선수로서 성추행, 성폭력 그런 거 너무 안타깝죠. 그런 게 되게 수치스 러울 수 있잖아요. 그 사람에게 받은 피해로 내가 온전하지 않은데, 그게 언 론으로 나가고 이걸 밝혀야지만 이 사람을 더 벌 받게 할 수 있는 거잖아요. 선수에게는 꼬리표 같은 거죠. 내부의 일을 다른 사람에게 이야기하면 배신 자 이미지가 될 거고. 그런 두려움이 많이 있죠." (연구참여자 F)

"내가 폭행을 당했어. 라고 신고를 하면 일이 커지고, 팀을 해체해버리잖아 요. 그럼 선수도, 다른 팀원들도, 지도자도 모두 일자리를 잃게 되니까요. 신 고하기가 어렵죠." (연구참여자 O)

"문제제기를 해도 달라진 게 없어요. 협회 쪽은 그쪽 편이고, 체육회도, 경찰 서도 잘 모르겠어요. 문제를 터트리고 문체부 감사까지 가는데 2주나 걸렸 어요. 그리고 경찰에 넘어갔는데요. 이미 훈련장에 있는 컴퓨터 증거는 다 없어졌죠. 안타깝죠. 그 사람들은 말로만 사퇴하고, 다른 데서 다 활동하고 있어요. 결국 우리만 운동하는 데 제재를 더 당했죠. 해도 안 되는구나. 허무 함만 더 커지죠." (연구참여자 C)

\section{2) 연맹문제 공론화의 어려움}

선수들은 연맹의 일률적인 법적용으로 이적시장이 소멸되고 있다고 언급했다. 이적을 시도하면 연맹에 불려가서 위압적으로 진술을 요구받 는 것으로도 나타났다. 1 등에게 몰리는 지원시스템, 비인기종목의 홍보 등한시, 남자 선수의 병역문제 등 연맹 문제를 공론화하고자 국민청원에 올렸지만, 소수라서 청원글이 뜰 정도로 눌리지 않았고, 글을 올린 선수 에게만 보복이 들어갔다고 했다.

"실업연맹법이 어느 날 갑자기 만들어졌어요. 선수들 기록이 점점 떨어지다 보니, 기록을 정해놓고 이 기록이 아니면 계약금을 줄 수 없다는 규정을 만 들어놓은 거예요. 기록 대비 계약기간, 선수연봉, 선수계약금을 정해요. 그 기록을 내는 선수들은 우리나라에 몇 없는데, 그걸 위반하면 선수는 2년 정 지를 받아야 해요. 다 강압적인 거예요. 시군청, 감독들 입장에서는 실업연 맹법이 무조건 좋죠. 좋은 선수를 싸게 데리고 올 수 있으니까요. 그뿐만 아 니라 계약금을 한 번 받으면 다음 팀으로 이적할 때는 계약금을 못 받아요. 연봉만 받아요. 고등학생이나 대학생 선수들이 졸업해서 계약하게 되면 한 팀에서 7년 계약을 해요. 만약 고등학생이나 대학생 선수가 그때의 기준 기 록을 통과하지 못하면 연봉을 적게 받으면서 7년을 있는 거예요. 이적시장 이라는 게 아예 없어진 거죠." (연구참여자 J)

“소속을 옮기면서 하프 마라톤 기준 기록을 통과했어요. 그러면 3천만 원을 받을 수 있어요. 계약 위반은 아닌데, 연맹에서 연락이 왔어요. 너는 실업연 맹법을 위반한 선수로 의심이 간다. 저를 둘러싸고 지도자들이 계약금을 얼 마 받았냐? 몇 년 했냐? 말해라. 통장 내역을 다 확인할 수 있다. 꼬치꼬치 캐물었어요. 그것도 인권인데, 그런 게 아예 보호가 안 되는 거예요." (연구 참여자 I)
“정책적으로, 랭킹 1등만 지원을 많이 해주거든요. 해외 훈련이나 시합이요. 그러다 보니 나머지 선수에게 기회가 없죠. 한 명만 지원해주니 그 사람만 기량이 좋아지는 거죠. 종목홍보도 연맹에서 해줘야 하는데 오히려 은퇴한 선수들이 자진해서 하고 있어요. 클럽 활동으로 아마추어 선수들과 교류하 면서 홍보하고 있어요" (연구참여자 C)

"운동선수가 군대 가면 은퇴하는 거나 마찬가지죠. 군대 갔다 오면 이미 선수 몸은 다 망가진 상태이고, 나이도 많아진 상태이니 힘들죠. 예전에는 경찰청 팀, 상무팀 이렇게 두 군데가 있었어요. 지금은 경찰청팀은 없어져 버렸고, 상무는 비리에 걸려서 선수를 몇 명 안 뽑아요. 뽑는 인원이 적어지니 경쟁 이 더 치열하죠. 전에는 상무팀에 2-3천만 원을 내고 군대에 갈 수 있었거 든요. 상무처럼 운동하면서 군복무를 할 수 있는 길을 많이 열어 주는 게 연 맹의 일인데, 그런 건 전혀 신경을 쓰지 않아요." (연구참여자 F)

\section{5. 남성 중심적 운동환경 속 (성)차별 경험: 성과보다 성별}

남성 중심 문화에 서 있는 여성 선수는 성과보다 성별로 인권침해를 경 험하고 있었다. '여성 선수의 불안전한 운동환경', '결혼- 임신-출산 및 연속되는 어려움', '여성 지도자가 뚫기 힘든 유리천장' 등 세 개의 주제 모음이 나타났다.

\section{1) 여성 선수의 불안전한 운동환경}

여자 선수는 생리주기와 관련해서 남자 지도자와의 소통을 포기하는 것으로 나타났다. 생리 기간에 신체적으로나 정서적으로 힘들지만, 지도 자가 무서워서 대화가 어렵다고 했다. 감독이 남자 선수와 여자 선수의 기량 차이를 비교하며 무시하는 성차별 비하 발언을 하고, 여자 선수가 남자 선수들보다 비싼 몸값을 받는다며 더 심한 성과압박을 한다고 했 다. 감독 술자리에 여자 선수가 불려 나가거나 강압적으로 지인을 소개 받는 등 부당한 대우를 받아도 불이익을 받을까 봐 말을 못 꺼내는 것으 로 나타났다. 지도자 혹은 선배의 성희롱 사례도 언급되었다.

"생리 기간에 정서적으로 예민해져서 민감한데요. 어차피 감독님 성격이 워 낙 불같으시니까 무서워서 선뜻 말할 수가 없어요. 다혈질이라 어차피 대화 가 안 되니까요. 생리통으로 힘들면 그냥 약 먹고 운동해요." (연구참여자 A1)

"여자 선수들은 남자 선수들보다 몸값이 비싸요. 인원이 적다 보니까 그런 것 같은데. 그런 걸 문제 삼아 성과압박을 하죠. 넌 이 정도 받는 선수인데 왜 못하냐. 남자랑 여자랑 신체적으로 다르잖아요. 근데 남자 쪽에서 금방 넘어 온 분들은요. 우리가 잘 안 되면 '여자들은 이게 안 되네' 이러거든요. 파워 나 스피드가 애초에 다른데 비교를 해요." (연구참여자 O)

“군청 관계자들 술자리에 맨날 끌려 나가요. 시합이 일주일 남았는데, 감독님 이 누구하고 친분을 쌓기 위해 술자리를 만들었다. 술자리에 나와라 그래요. 7일 중 7일을 술을 마신 선수도 있었어요. 저녁에 시작된 술자리가 다음날 끝난 적도 있었어요. 감독의 지인을 소개받은 적도 있어요. 강압적으로 그냥 계속 연락하라고요. 싫다고 하면 불이익을 받으니까 어쩔 수 없죠." (연구참 여자 P1)

"시합 끝나고 카메라가 집중됐을 때 감독님한테 뛰어와서 두 팔 벌려 가슴으 로 안기지 않았다고 화가 난 거예요. 선생님을 남자로 보냐고, 왜 와서 못 안 기냐고 그랬어요. 가정교육을 잘못 받은 거라고. 심지어 아시안게임 중에 어 떤 지도자는 고등학생 여자 선수를 술 마실 때 무릎 위에 앉혔어요. 남자 선 배들도 심해요. 술 마실 때 불러서 옆에서 술 따르라고 하고, 먹으라고 하고, 왕게임하고 그런 경우도 많죠. 여자 선수가 치장하거나, 남자 선수와 다니면 재 남자 밝히네. 연애하네. 그러죠." (연구참여자 $\mathrm{H}$ ) 


\section{2) 결혼- 임신-출산의 연속되는 어려움}

여자 선수들은 결혼- 임신 - 출산의 연속되는 어려움에 놓여 있는 것으 로 나타났다. 선발명단에서 제외되거나, 은퇴를 종용당하는 불이익을 받 기 때문에 팀의 이해도에 따라 결혼 혹은 임신 계획을 세운다고 했다. 출 산 후에는 주부로서의 고충, 선수로서의 고충으로 육아와 선수 생활 양 립의 힘든 점을 언급하였다.

"결혼을 은퇴 직전 1-2년 전에 하죠. 현역 때 결혼했다면 출산은 최대한 미 루려고 하고요. 그러다 보니 모성보호 제도를 쓸 필요가 없죠. 제가 아이를 가지려고 준비한다고 했을 때부터 명단에서 제외했어요. 아기 낳고도 나는 자신있다 할 수 있다고 했는데 감독이 ‘할 수 있어? 힘들걸?’ 이러더라구요. 애 낳고 30 대 중후반 되면 다들 그만두죠." (연구참여자 M1)

“주부로서의 고충이 크죠. 아이 보느라 잠을 못 자죠. 저는 친정엄마가 아이 를 돌봐주세요. 운이 좋은 거죠. 제가 아는 선수는 친한 언니한테 아이를 맡 겼어요. 선발되면 선수촌 입촌해야 하는데 아이는 어떻게 하나 걱정하더라 고요." (연구참여자 D1)

\section{3) 여성 지도자가 뚫기 힘든 유리천장}

체육계에서 여성 지도자가 남성 지도자보다 성과를 더 내는 경우도 많 이 있다. 하지만 소규모 종목이라 여자선수층이 얕고, 여자실업팀까지 없다 보니 아무래도 협소한 지도자 진로에 놓여 있다고 언급했다. 또한 남성 중심으로 서로 밀어주는 스포츠 문화에서 여성 지도자의 어려움이 나타났다.

"소규모 종목은 여자선수층이 많이 약해요. 전국에 다 해도 10 명이 안 돼요. 여자실업팀이 없으니 대학까지만 가고 다 그만둬요. 여자 선수가 지도자로 가기는 힘들죠. 현재 여자 감독은 없어요. 여자들은 코치로 간다고 해도, 하 다가 그만두는 경우가 많아요. 여자 지도자들은 여자팀만 맡게 되는 경우 가 많은데 그 팀이랑 맞지 않으면 그만두게 되는 거죠. 사실 여성 지도자들 이 오히려 성과를 많이 내세요. 여성 지도자는 판단 능력이 되게 빨라요. 문 제점을 이성적으로 파악하고, 세심하게 가르쳐주고, 감정적인 부분을 마음 써주니, 선수가 가까이 다가갈 수 있어요. 육상에서 날리는 선수가 하나 있 어요. 중학교 선수인데 국가대표급 실력이죠. 그 애를 키운 지도자분도 여성 분이세요. 어 저런 애를 남자가 아니라 여자가 키웠어? 이런 의식이 아직 있 죠. 국가대표 전임지도자도 여성분 있어요." (연구참여자 M1)

“남성들의 문화이다 보니 여성 지도자가 고위직에 끼기 어려워요. 협회 임직 원, 지도자, 위원회 분들이 다음번에 네가 감독해 그러면서 남자를 밀어주고 요. 협회에도 위원회 이사진에 여성 지도자를 넣어야 해요. 여자들의 의견도 들어야 하잖아요." (연구참여자 A2)

\section{논의}

본 연구는 실업팀 직장운동선수들이 경험하는 인권침해 현상의 본질을 파악하고, 그 의미를 탐색하였다. 이를 위해 실업팀 직장운동선수 35 명 을 대상으로 심층면담과 FGI를 실시하였다. 연구결과, 5 개 범주, 14 개 의 주제모음, 41 개의 주제가 도출되었으며 주요 연구결과와 그에 따른 시사점을 논의하면 다음과 같다.

첫째, '실업팀 선수가 되는 첫걸음: 불합리한 선수계약' 범주에서 주제 모음으로 나타난 것은 선수 의견이 무시된 계약, 지나친 경기성적 압박, 소속팀 위주로 바뀌는 재계약서였다. 실업팀 직장운동선수들은 학교 제 도 안에서 벗어나면서 학생에서 근로자의 신분으로 전환되었다. 근로자
는 직업의 종류와 관계없이 임금을 목적으로 사업이나 사업장에 근로를 제공하는 자를 의미한다(Yoo, 2017). 선수들은 근로기준법상 근로자에 해당되지만 연장, 야간, 휴일근로수당, 연차휴가수당 등 법정수당을 제 대로 지급받지 못하고 있었다. 이와 같은 신분상(근로자)에 인권문제가 존재하는 것은 학교 제도 안에서는 찾아볼 수 없는 문제점이다. 최근, 정 부는 체육계에 표준계약서를 도입하기로 했다(Kim, 2021). 표준계약서 에는 선수의 연장, 야간, 휴일, 근로수당 지급이 명시되어 있고 폭력, 성 희롱, 인권을 손상당하는 범죄를 당한 경우, 선수가 계약을 해지할 수 있 도록 했다. 인터뷰 결과, 여러 선수들이 근로자로서 보장되어야 하는 법 정 휴가 사용을 자율적으로 하지 못하거나, 관련 수당 지급을 적절히 받 지 못하고 있음을 언급했다. 이는 운동선수의 일터로서 실업팀이 적절히 기능하지 못하고 있음을 방증하므로 개인이 아니라 조직적 관리 차원의 대책 마련이 요구된다. 또한 운동만을 해 온 선수들이 사회인으로서 기 본적으로 누려야 할 권리를 인지할 수 있도록 다양한 교육의 기회가 주 어질 필요가 있다고 사료된다. 더불어 선수 교육뿐 아니라 실업팀의 적 절한 노동 환경 혹은 근무 조건 마련에 협회와 연맹, 지도자 등 관리/감 독 주체의 적극적 노력과 대책 마련이 전제되어야 한다. 결국, 개인에 대 한 인권교육뿐 아니라 조직적, 관리 책임을 강조하는 방향의 진단과 대 책이 좀 더 보완되어야 할 것이다.

둘째, '피할 수 없는 절대적 권력자: 코치, 감독에게 복종' 범주에서 주 제모음으로 나타난 것은 지도자의 언어 및 신체적 폭력, 지도자 권한 남 용, 지도자와의 불화로 인한 인간관계 고립이었다. 본 연구에서 실업팀 직장운동선수의 인권침해 주요 가해자는 지도자로 나타났으며, 선수들 의 인권침해 피해 경험은 우울증 및 자살로까지 이어지는 심각한 수준이 었다. 선수에게 지도자는 계약, 재계약, 선수기용, 방출, 그리고 진로까 지 영향을 미치는 사람이다. 선수들은 개인적 보복과 불이익 때문에 부 당한 대우에도 소극적으로 대처할 수밖에 없다고 언급했는데 이러한 부 분은 선행연구 결과를 지지하고 있다(Huh et al., 2020). 스포츠계에서 지도자와 선수 간의 폭행 문제는 어제, 오늘의 일이 아니다. 그럼에도 불 구하고 근본적인 해결은 뒤로하고 일시적인 미봉책으로 관련자 처벌과 징계에 중점을 두고 있다(Choi \& Choi, 2020). 지도자에 의한 선수들 의 인권침해를 예방할 수 있는 근본적인 해결책은 지도자의 인권 감수성 (human rights sensitivity) 신장일 것이다. 인권 감수성이란 인권문제 가 개재된 상황에서 그 상황을 인권 관련 상황으로 지각 및 해석하고, 그 에 따른 행동이 다른 당사자들에게 어떠한 영향을 미치는지를 알며, 그 상황을 해결하기 위한 책임이 자신에게 있다고 인식하는 심리적 과정이 다(Moon, 2006). "감독이 욕하면 욕먹고, 시키면 하는 게 맞는 거죠. 선 생님하고 제자 사이인데 그게 예의라고 생각해요. 제가 좀 보수적이라 그런지, 맞았던 것 이상으로 선생님들에게 인성을 배웠고, 내 운동의 밑 거름이 되어서 좋은 것만 생각나요. 항상 감사해서 찾아뵙고 그래요. 제 가 못 해서 맞았으니까요. 지도자도 자기 선수가 못하면 화가 나니까 때 리는 거지, 오늘 재 때려야지 하면서 때리는 건 아니거든요." 위의 내용 은 2019년 국가인권위원회 실업팀 직장운동선수 인권침해 실태조사에 서 나타난 결과이다. 언급된 내용에서 스포츠계의 인권 감수성에 상대적 으로 관심이 부족했음을 확인할 수 있다. 2021년 6월 9일부터 3차 개정 된 「국민체육진흥법」이 시행됨에 따라 체육지도자는 2년마다 인권교육 을 포함하는 재교육을 의무적으로 받아야 한다. 인권교육에서 강조되어 야 할 인권 감수성이 왜 필요한지, 어떻게 실천할 수 있는지에 대한 구체 적인 답변이 부재한 상황에서 인권교육과 관련된 정책적 방안과 제도적 장치를 마련한다는 것은 의미가 없을 것이다. 실효성을 고려한다면 무엇 보다도 인권 감수성 신장을 위해 인권교육에 문화적 이해와 다양성을 반 
영되어야 한다. 국제적으로 인권교육은 교육의 일부가 아닌 하나의 권리 로 정립되어 가고 있으나, 여전히 우리의 교육 현황은 인권교육을 교육 의 일부로 실시하고 있는 실정이다( $\mathrm{Na}, 2011)$. 인권침해 상황을 올바르 게 판단할 수 있도록, 인권을 존중하는 구체적인 방법을 익힐 수 있도록 도움을 주어야 할 것이다.

셋째, '강제 합숙소 생활: 자율성 및 사생활 침해' 범주에서 주제모음 으로 나타난 것은 내부지침으로 자율성 통제, 운동시간 외 사생활 침해, 위계적 선후배 문화였다. 선행연구들에서 밝혀진 바와 같이 선수들은 어 린 시절부터 폐쇄적 합숙문화로 매우 제약된 활동을 하고 있다(Myung, 2017). 또한 대다수의 학교 운동부 합숙소는 열악한 숙식 시설과 비위생 적 환경에 노출되어 있다(Ku, 2009; Park, 2015). 실업팀 합숙소의 상 황도 유사함이 본 연구에서 확인되었다. 실업팀임에도 불구하고 제대로 된 근로환경조차 마련되어 있지 않았다. 연구참여자는 "솔직히 운동을 잘하려고 실업팀까지 간 건데 운동을 그만두게 하는 요소가 더 많아요.” 라고 언급하였다. 이 실업팀은 예산 부족으로 체육회관을 합숙소로 빌려 쓰고 있었고, 식당 운영이 어려워서 선수끼리 끼니를 해결하고 있었다. 가족 및 타인과 단절된 생활 속에서 인권침해 문제는 더욱 심화되었다. 2003년 일명 '천안초등학교 축구부 합숙소 화재 참사'로 학교 운동부 합 숙 훈련에 대한 규제는 강화(Ahn, 2016)되었지만, 학교제도 밖에 있는 실업팀 합숙소의 상황은 고려되지 않고 있다. 직장운동부 합숙소 생활에 는 경기력 향상이라는 긍정적 요인과 반인권적 생활 통제라는 부정적 요 인이 상존한다(Huh et al., 2020). 하지만 본 연구에서 나타난 실업팀 합 숙소 생활의 문제점들은 합숙소가 전면 혹은 점차적으로 폐지되어야 한 다는 정책적 방향을 대변하고 있다. 실업팀 직장운동부의 근로환경 개선 은 선수의 인권적인 측면에서 반드시 해결해야 할 문제이므로 본 연구에 서 나타난 다양한 문제들을 바탕으로 제도적 개선방안이 제시되어야 할 것이다.

넷째, '실업연맹의 구조적인 문제: 힘을 가진 자의 횡포' 범주에서 주 제모음으로 나타난 것은 문제제기시 불이익 및 낙인의 2차 피해 우려, 연맹문제 공론화의 어려움이었다. 우리나라에서 스포츠 단체의 불법행 위는 이제 흔한 일이 되어버렸다. 처벌받지만 기준이 모호하여 가해자가 오히려 복귀 후 당당히 활동하고 있다. 본 연구에서 실업연맹의 구조적 문제점은 대부분 조직 사유화의 결과 혹은 과정에서 불법행위가 나타났 다. 조직 사유화는 구성원의 공익을 목적으로 설립된 단체가 아주 극소 수 특정인에 의해 그 행위를 결정하고 피해자를 양산해내는 조직의 불합 리한 운영을 의미한다(Chung et al., 2012). "문제제기 해도 달라진 게 없어요. 힘없는 선수는 당하는 거고, 힘 있는 사람은 그냥 그대로 웃으며 재밌게 지내는 거죠."라며 선수들은 학습된 무기력을 호소하였다. 우리 나라의 스포츠법 제도 내에서 이를 절대적으로 예방하기 어려우므로 제 도적 보완책이 시급히 마련되어야 할 것이다. 현재, 국회 법제사법위원 회에서 논의되고 있는 '스포츠특별사법경찰제도'가 도입되어 폐쇄적 환 경에서 발생하는 체육계인권침해·비리를 전문성을 기반으로 수사해야 한다. 이를 통해 스포츠 단체의 조직 사유화와 각종 불법 행위간의 진실 을 규명할 수 있기를 기대한다.

다섯째, “남성 중심적 운동환경 속 (성)차별 경험”: 성과보다는 성별' 범주에서 주제모음으로 나타난 것은 여성 선수의 불안전한 운동 환경, 결혼- 임신-출산의 연속되는 어려움, 여성지도자가 뚫기 힘든 유리천장 이었다. 실업팀 직장운동부는 특히 여자 선수들의 인권침해에 취약한 환 경이다(Huh et al., 2020). 회식강요, 성차별, 성희롱 발언 등의 인권침 해 경험은 여자 선수들의 자존감과 경기력, 심리적- 신체적 안정에 부정 적인 영향을 미친다(Heo et al., 2008). 이와 관련하여 본 연구에서 흥미
로운 부분이 나타났다. 대부분의 여자 선수들이 성희롱 및 성폭력에 해 당하는 행동들을 인식하고 있지만, 가해자의 유사한 인권침해 행동에 대 해서는 개인에 따라 다르게 인식하고 있었다. 이러한 결과는 성희롱 및 성폭력과 관련하여 개인 인식의 차이를 주장한 선행연구를 지지하였다 (Fasting et al, 2003). 또한 여자 선수들은 훈련 상황에서의 신체접촉은 불가피하지만, 훈련이 아닌 상황에까지 신체접촉이 이어지는 것이 힘들 다고 언급했다. 이러한 부분은 신체적 접촉이 빈번한 종목일수록 남자 지도자와 여자 선수 간의 성폭력 행동의 빈도가 높으며, 여자 선수가 남 자 지도자의 행동이 성폭력인지 아닌지를 구분하기 어려워한다는 선행 연구(Donelly, 1999)와 부분적으로 일치하였다. 어린 여자 선수는 남자 지도자를 친구이자 아버지의 모습으로 인식할 수 있으며, 지도자는 이러 한 친밀성을 부적절한 행동에 악용한다고 보고되었다(Nielsen, 2001). 본 연구에서도 신체적으로 성장한 성인이 된 선수를 여전히 어린 선수처 럼 대하는 남자 지도자들이 다수 존재하며, 이들로 인하여 여자 선수들 이 인권침해를 경험하는 것으로 나타났다. 일반적인 성범죄와 달리 체 육계의 성범죄는 위계 구조에 의한 권력이나 지위로 시작된다(Kim \& $\mathrm{Kim}, 2019)$. 자기주장이 강한 독립적인 여자 선수라 할지라도 남자 지 도자의 권위에 도전하지 못하는 경우는 많다(Volkwein et al, 1997). 더 욱이 지도자는 계약, 재계약, 선수기용, 방출, 그리고 진로까지 영향을 미치는 사람이다. 이러한 맥락은 실업팀 직장운동부 여자 선수가 인권침 해를 당해도 아무런 행동을 취하지 않는 등의 소극적인 대처방식을 선택 할 수밖에 없는 이유를 설명해준다.

한편 스포츠 현장은 남성 중심의 사고가 강하며 여성의 특수성에 대한 배려는 미흡한 실정이다(So \& Kwak, 2018). 임신 및 출산은 여성 신체 에서 일어나는 고유한 경험이며, 여성의 정체성과 삶에 여러 구조적 영 향을 미치는 사회적 경험이다. 그런데 실업팀 직장운동부 여자 선수에게 결혼, 임신, 출산이라는 단어는 선발배제, 은퇴종용, 경력단절의 의미로 다가온다고 언급했다. 출산 이후, 선수들은 제한적인 고용기회를 얻는 다. 주변에 자녀 보육 대행자가 있는 경우에만 복직 여부가 결정되기 때 문이다. 어린 자녀가 있고 일을 하는 여성에게 근무시간 동안 자녀를 돌 봐주는 것은 다른 어떤 지원보다 중요하다( $\mathrm{Ha}, 2010)$. 스포츠에서 성평 등이 이루어지고 있는가를 알수 있는 방법은 선수와 지도자의 양성이 이 루어졌는가를 확인하는 일이다(Joo, 2010). 실업팀 직장운동부는 여성 지도자 비율이 절대적으로 낮은 성 불평등 구조이다. 전체 지도자 중 여 성 코치가 $13.2 \%$, 여성 감독이 $6.1 \%$ 로 나타났다. 특히 여성 감독은 여성 코치의 절반에도 못 미쳐 주요 결정권자로 갈수록 여성 지도자 비율은 심각한 불균형을 보인다(Huh et al., 2020). 앞에서 언급했던 성폭력의 예방을 위해서 여성 지도자의 역할은 중요해지고 있다. 성별 이분법적 시각에서 벗어나 동등한 인간으로 바라볼 수 있는 인권적인 시각을 마련 하기 위해서, 실업팀 직장운동부 여자 선수를 위한 사회적, 제도적 뒷받 침은 반드시 필요 사항이라 볼 수 있다.

본 연구는 현상학적 연구 방법의 장점을 활용하여 기존의 연구에서 다 루기 힘들었던 실업팀 직장운동선수의 인권침해 경험을 생생하게 드러 낼 수 있었다. 인권이 문화적 상황 속에서 실제로 실현되기 위해서는 상 황의 특수성을 고려해야 한다. 무엇보다도 실업팀 직장운동선수들을 근 로자로 바라보는 인식이 한층 더 개선되기를 바란다. 인권이 실업팀 직 장운동부 모든 선수에게 보편적인 권리가 될 때까지, 일상생활 속에서 자연스럽게 스며드는 방안이 마련되어야 할 것이다. 마지막으로 인권에 서 더 나아가 진로 문제, 역량증진 등과 같은 문제를 개선할 수 있는 프 로그램이 개발되어 그들의 삶의 질이 향상되기를 바란다. 


\section{결론 및 제언}

본 연구는 실업팀 직장운동선수를 대상으로 인권침해 경험에 대해 탐색 해보았다. 이를 위해 실업팀 직장운동선수를 대상으로 심층면담 및 FGI 를 실시하고 그 내용을 다섯 가지의 본질적인 구조로 나누어 분석한 결 과 다음과 같은 결론을 도출하였다. 첫째, 근로자임에도 불구하고 불합 리한 선수계약을 경험하고 있었다. 둘째, 언어 및 신체적 폭력에 시달리 면서 절대적인 권력자인 지도자에게 복종하고 있었다. 셋째, 강제 합숙 소 생활을 하며 자율성 및 사생활을 침해당하고 있었다. 넷째, 실업연맹 의 구조적인 문제로 힘을 가진 자들의 횡포를 감내하고 있었다. 다섯째, 남성 중심의 사고가 강한 스포츠 현장에서 여자 선수들은 젠더에 기반한 차별 문제로서 인권침해를 경험하고 있었다.

실업팀 직장운동선수 인권 보호를 위한 대안을 제안해보면 다음과 같 다. 첫째, 실업팀 직장운동선수들을 근로자로 바라보고 인식이 개선되어 정부 차원에서 체계적인 관리시스템이 마련되어야 한다. 임금을 제대로 지불하고 있는지, 출전의 기회를 균등하게 배분하고 있는지, 임금과 퇴 직금을 보장하고 있는지 등 실업팀 관리자들을 대상으로 점검해야 한다. 동시에 선수들이 관리자와 지도를 평가하는 장치도 마련되어야 한다. 둘 째, 주기적인 인권교육의 대상에 선수, 지도자는 물론 실업팀 관련자들 까지 포함해야 한다. 선수들에게는 자신의 권리를 주장할 수 있는 역량 을 마련해주고, 나아가 지도자 및 실업팀 관련자들이 선수에게 의식적, 무의식적으로 가해지는 차별적인 행태를 줄이기 위함이다. 셋째, 선수들 이 편하게 상담하고 자신의 권리를 구제받는 오프라인 및 온라인 상담플 랫폼이 마련되어야 한다. 선수들이 언제 어디서든 쉽게 접속할 수 있고, 자신이 거주하는 지역에서 자신이 당면한 문제에 가장 적합한 전문가를 찾을 수 있도록 연결해 주어야 한다. 전문가를 통해 다양하고 정확한 인 권정보로 자신의 권리를 자신이 지킬 수 있는 기회를 제공해야 한다.

이를 바탕으로 다음과 같이 후속연구를 제안하고자 한다. 본 연구는 어디까지나 선수의 관점에 기초하고 있는 연구이다. 실업팀의 세 주체 중 나머지 두 주체인 지도자, 실업팀 관리자의 경험을 담아내지는 못하 였다. 후속연구에서는 실업팀 인권침해를 둘러싼 여러 이해 관계자들을 대상으로 경험의 의미를 탐색하는 질적 연구가 이루어지기를 제안한다. 또한 본 연구는 선수의 경험에 한정하여 진행한 연구이다. 본 연구의 결 과를 전체 실업팀 구성원으로 확대하여 해석하기에는 다소 무리가 있을 것이다. 이에 선수보다 풍부한 경험을 가진 지도자 혹은 전문가의 경험 을 바탕으로 연구를 수행한다면 좀 더 현실과 가까운 결과를 도출할 수 있을 것으로 판단된다.

\section{참고문헌}

Ahn, M. S. (2016). My Nostalgic House: Current Status of Athletic Dormitory and Life of Student Athlete. Diagnostic report of the National Audit Policy for 2016. Seoul: Education, Culture, Sports, and Tourism Committee of National Assembly.

Choi, Y. L. \& Choi, C. (2020). Elite Sports Coaches' Perception of Sports Ethics: A Mixed-Method Study. The Korean Journal of Physical Education, 59(6), 143-155.

Chung, T. R., Cho, K. M.. \& Nam, S. B. (2012). A Study on the Civil Liability on Tort Action -Centering around the case of Korean Woman`s Badminton Doubles Team for the 2012 London Olympic Games-. Korean Journal of Sport Management, 17(6), 57-69.

Colaizzi, P. F. (1978). Psychological research as the phenomenologist views it.

Donnelly, P. (1999). Who's Fair Game? Sport, Sexual Harassment and Abuse, In P. White and K. Young (eds) Sport and Gender in Canada. Toronto: Oxford University Press.

Fasting, K., Brackenridge, C., \& Sundgot-Borgen, J. (2003). Experiences of sexual harassment and abuse among Norwegian elite female athletes and nonathletes. Research quarterly for exercise and sport, 74(1), 84-97.

Go, G. (2019). A Comparative Law Study for the Guarantee of Sports Rights. The Journal of Sports and Entertainment Law, 22(4), 123-143.

Ha, H. (2010). A Study on Counseling Approach for Child Care. Social Science Research Institute, Jeonju University, 26(1), 17-31.

Han, S. \& Yoon, J. (2020). Understanding the Structure of Tourism Experience in Autobiographical Memory. Journal of Tourism Sciences, 44(8), 33-54.

Heo, H. M., Hwang, J. I.., \& Sun, B. Y. (2008). A study on the sexual harassment and abuse of professional female athletes. The Korean Journal of Physical Education, 47(4), 77-89.

Huh, J. H., Kim, E. J., \& Ko, K. H. (2020). Research on the human rights violation of semi-professional athletes in the workplace. Korean Journal of Sport Science, 31(4), 728-744.

Jang, C., Lim, T., Bae, J., \& Kim. N. G. (2020). Development of the Life Skills Program for Student-Athletes Using Multi-Dimensional Approaches. Korean Journal of Sport Psychology, 31(4), 1-16.

Joo, J. M. (2010). Article : Institutional Plans for Hiring of Athletic Coach by Gender Equity. The Journal of Sports and Entertainment Law, 13(3), 211-239.

Kang, G. M. (2010). The Constitutional Implication for Student Athletes of Their Rights to Learn. The Journal of Sports and Entertainment Law, 13(4), 101-120.

Kim, C. S. (2021). https://blog.daum.net/kcs9222/17209381

Kim, D., \& Choe, S. (2011). Actual condition and development plan of safety right protective policy for student athletes, The Journal of Sports and Entertainment Law, 14(4), 123-153.

Kim, H., \& Park, S. (2020). Human Rights Policy Analysis and 
Improvement Direction in Sports: Focusing on the Protection of Right for Learning. The Korean Journal of Physical Education, 59(5), 13-30.

Kim, Y. R. (2010). The Analysis of News Framing on Human Rights of Student Athletes. Korean Journal of sociology of sport, 23(3), 37-53.

Kim. B. J \& Kim. J. H. (2019). Sports Human Rights Blind Spot: Taekwondo Player Human Rights Problems and Social Responsibility. Journal of Philosophy of Movement, 27(2), 3544.

Ku, J. W. (2009). A Training Camp for Youth Ssireum Players Positive and Negative Element. Unpublished Master's dissertation. Incheon National University.

Lee, H. J., \& Ahn, Y. (2014). Directions for lives of student Athletes in University. Sport Science, 31(2), 111-122.

Lee, N. I. (2014). Phenomenology and qualitative research. Gyeonggi: Hangilsa Publisnig Co., Ltd.

Lincoln, Y. S., \& Guba, E. G. (1985). Establishing trustworthiness. Naturalistic inquiry, 289(331), 289-327.

Moon, J., \& Kim, S. (2020). A study on the introduction of a special judicial police officer system to guarantee the human rights of athletes. The Journal of Sports and Entertainment Law, 23(3), 77-92.

Moon, M. H. (2006). The Development and Validation of a Human Rights Education Program for Preservice Teachers: Based on the Rest's Four Component Model of Morality. Journal of Educational Psychology, 20(2), 341-362.

Morrow, R., Rodriguez, A., \& King, N. (2015). Colaizzi's descriptive phenomenological method. The psychologist, 28(8), 643-644.

Myung, W. (2017). The socio-cultural background and the current issues of camp training system in school sport. Korean Journal of Sport Science, 28(3), 592-607.

Na, D. S. (2011). Current State and Tasks in home and abroad Human Rights Education. The Journal of Law of Education, 23(1), 85121.

National Human Rights Commission of Korea (2019). 2019 Research on the human rights violation of semi-professional athletes in the workplace. Seoul: 두루행복한세상.

Nielsen, J. T. (2001). The forbidden zone: Intimacy, sexual relations and misconduct in the relationship between coaches and athletes. International review for the sociology of sport, 36(2), 165-182.

Park, S. L. (2015). An Study Plan for Training Camp Living and Leisure Utilization of University Athletic Clubs Based on Actual Condition Analysis: With a Special Emphasis on Rowing. The Journal of Yeolin Education, 23(2), 109-127.

So, Y. \& Kwak, J. (2018). Discussion about Career Discontinuity and Reinstatement limitation Factors of Female Taekwondo Master. Taekwondo Journal of Kukkiwon, 9(2), 63-87.

Song, N. S., \& Lee, J. H. (2015). Performance role task for increase of sport human rights in school athlete coach. Jounal of Korean Society of Sport Policy, 32, 29-50.
Volkwein, K. A., Schnell, F. I., Sherwood, D., \& Livezey, A. (1997). Sexual harassment in sport: Perceptions and experiences of American female student-athletes. International review for the sociology of sport, 32(3), 283-295.

Yoo, G. (2017). A brief review on the labor law Issues on the contract for professional baseball players. The Journal of Sports and Entertainment Law, 20(3), 91-108.

Yu, J., Kim, J., \& Yoon. H. (2020). Normative System of the Sport Human and National Responsibilities. The Journal of Sports and Entertainment Law, 23(4), 75-95. 


\title{
직장운동선수의 인권침해 경험에 대한 현상학적 연구
}

\author{
한시완 ${ }^{1}$, 유현미 ${ }^{2}$ 허정훈 ${ }^{3}$
}

1 동국대학교 인공지능융합연구센터 연구원

2 서울대학교 사회학과 박사수료

3 중앙대학교 스포츠과학부 교수

[목적] 본 연구는 실업팀 직장운동선수들이 경험하는 인권침해라는 현상의 본질을 파악하고, 그에 대한 사례를 탐색하는 데 목적을 두었다.

[방법] 이를 위해 실업팀 직장운동선수 35명(남: 20명, 여: 15 명)이 참여하였으며 자료수집은 심층면담과 FGI를 통하여 이루어졌다. 수집된 자료는 Colaizzi(1978) 현상학적 연구방법을 활용하여 분석하였다.

[결과] 연구결과, 5 개 범주(categories), 14 개의 주제모음(theme clusters), 41 개의 주제(theme)로 도출되었다. 본질적 구조로는 '실업팀 선수가 되는 첫걸음: 불합리한 선수계약' '피할 수 없는 절대적 권력자: 코치, 감독에게 복종', '강제 합 숙소 생활: 자율성 및 사생활 침해', '실업연맹의 구조적인 문제: 힘을 가진 자의 횡포', '남성 중심적 운동환경 속 (성)차별 경험: 성과보다는 성별’로 나타났다.

[결론] 본 연구결과는 실업팀 직장운동선수들의 인권침해 경험에 대한 이해를 제공하였다. 현상학적 연구를 통한 실업팀 직장운동선수에 대한 이해는 실천적, 정책적 개입 방안을 논의한 선행연구들을 토대로 논의하였다.

주요어

실업팀 직장운동선수, 인권침해, 경험, 현상학적 연구 